\title{
BANK HAJI INDONESIA : OPTIMALISASI PENGELOLAAN DANA HAJI UNTUK KESEJAHTERAAN JAMA'AH HAJI INDONESIA (SEBUAH GAGASAN)
}

\author{
Riko Nazri (11423004) \\ iko.nazri@gmail.com \\ Jurusan Ekonomi Islam FIAI Universitas Islam Indonesia
}

\begin{abstract}
ABSTRAKS
Writing in the scientif $c$ article is to give an idea of writing about the idea of established an Islamic fnance institution called Bank Haji Indonesia (BHI) as Financial institution that manages funds in full pilgrims collected up to trillions of rupiah each year in the Ministry of Religious Affairs of the Republic of Indonesia. Haji as the f ve pillars of Islam which was not only aimed at increasing piety and spiritual values of the perpetrators, but also save a great economic potential (Economic Hajj). The number of pilgrims from Indonesia is the most compared to other countries in the world that every year is always to obtain a quota of up to 200 thousand over the congregation. If we analyze each year there are 210215 candidate hajj with a 16 thousand pilgrims among Hajj plus. If the average is taken every pilgrims issued ONH (regular or plus) of Rp 30 million it will get the $R p 6.45$ trillion. From this simple calculation we get spending any pilgrims estimated to average USD 35 million. Up to by July 1, 2011 BPIH initial deposit ranging up to fgures collected $R p$. 31.34 trillion and the Ummah Endowment Fund of Rp 1.9 trillion. If the pilgrim fund can be managed optimally will certainly have an impact and benef ts for the welfare of pilgrims indonesia.
\end{abstract}

Keywords : Hajj, Islamic Banks, Hajj Economics, Hajj Fund, Optimalization Fund, Pilgrims Welfare

\section{PENDAHULUAN}

Haji sebagai rukun Islam yang kelima ternyata bukan saja bertujuan untuk meningkatkan ketakwaan dan nilai-nilai spritual pelakunya, namun juga menyimpan potensi ekonomi yang besar, lalu apakah Kementerian Agama sebagai penanggung jawab penyelenggaraan haji dan umrah selama ini sudah optimal dalam memanfaatkan potensi dana haji yang begitu besarnya mengalir setiap tahun di rekening Menteri Agama?, sudahkah pengelolaan dana haji selama ini memberikan manfaat banyak dan meningkatkan kesejahteraan serta pelayanan jama'ah haji Indonesia serta apakah bisa jika dana haji dikelola 
dengan optimal melalui lembaga keuangan Syariah yang khusus mengatur seluruh tata kelola keuangan haji memberikan dampak dan manfaat banyak bagi semua pihak yang terlibat didalamnya. Sehingga ada harapan besar melalui ekonomi haji dapat mendorong pertumbuhan perbankan Syariah nasional serta berkontribusi pula dalam pembangunan nasional.

Ibadah haji memiliki perbedaan dengan beberapa ibadah lain yang termasuk dalam rukun Islam yaitu memerlukan biaya yang relatif banyak mencapai puluhan juta rupiah. Nilai nominal sebesar itu bagi masyarakat Indonesia bisa dikatakan cukup mahal, mayoritas penduduk Indonesia tingkat kesejahteraannya berada dibawah garis kemiskinan. Bagi mereka yang berkecukupan secara f nansial, naik haji tentu tidak menjadi masalah. Namun bagi mereka yang tidak memilki cukup uang maka harus berusaha sekuat tenaga bekerja dan menabung untuk bisa menunaikan ibadah haji. Banyak umat muslim menabung di bank selama bertahuntahun atau melakukan usaha lainnya seperti menjual perhiasan atau hewan ternak supaya dapat melaksanakan impian banyak kaum muslim didunia ini, yakni beribadah haji ke tanah suci Mekkah. Walaupun mayoritas penduduk Indonesia tingkat kemampuan ekonominya rendah, namun setiap tahun kita menyaksikan ratusan ribu umat Islam Indonesia pergi menunaikan ibadah haji ke Arab Saudi setiap tahunnya.

Animo masyarakat muslim di Indonesia untuk melaksanakan ibadah haji ke tanah suci Mekkah adalah yang paling tinggi dibandingkan dengan negara-negara lain didunia, setiap tahunnya terjadi peningkatan, sekalipun pemerintah melalui Peraturan Menteri Agama No 6 Tahun 2010 telah menaikkan setoran awal bagi jama'ah haji reguler yang semula sebesar Rp 20 Juta menjadi Rp 25 Juta, dan haji khusus dari USD 3000 menjadi USD 4000. Sampai tanggal 7 Juni 2011 saja jumlah daftar tunggu (waiting list) jamaah haji Indonesia mencapai angka 1.420.915, terdiri dari 1.377.414 orang jamaah haji regular dan 43.501 orang jamaah haji khusus (Majalah Realita Haji, 2011).

Dan mari kita mencoba menghitung dan mencermati sekaligus membayangkan, jika setiap tahunnya ada 210215 calhaj (calon haji) dengan 16 ribu diantaranya haji plus. Jika diambil ratarata setiap calhaj mengeluarkan $\mathrm{ONH}$ (regular maupun plus) sebesar Rp 30 juta, maka akan mendapat angka Rp 6,45 triliun. Angka iniakan membengkak hingga Rp. 7,25 triliun bila setiap jamaah membawa bekal minimal 500 dolar AS. Dari kalkulasi sederhana ini kita mendapatkan pengeluaran setiap jama'ah haji diperkirakan rata-rata $\mathrm{Rp}$ 35 juta (Majalah Sharing, 2009).

Sedangkan berdasarkan laporan posisi keuangan pengelolaan $\mathrm{BPIH}$ 
1432H/2011M Direktorat Jenderal Penyelenggaraan Haji dan Umrah Kementerian Agama RI atas posisi dana setoran awal BPIH Per 1 juli 2011 berkisar pada angka Rp. 31,34 triliun lebih dan Dana Abadi Umat (DAU) sebesar Rp 1,9 triliun lebih (Majalah Realita Haji, 2011).

Lalu kini yang menjadi sebuah pertanyaannya ialah bagaimana kalau dana haji yang jumlahnya sangat besar tersebut dikelola dan dikembangkan oleh lembaga keuangan Syariah bernama Bank Haji Indonesia, mengingat sudah saatnya dana haji Indonesia dikelola penuh berdasarkan prinsip-prinsip Syariah seperti yang sudah dilakukan oleh Malaysia melaui Lembaga Tabung Haji (LTHM).

\section{KERANGKA TEORI}

Ibadah Haji sebagai rukun Islam

Haji adalah rukun (pilar agama) Islam yang kelima setelah syahadat, salat, zakat dan puasa. Menunaikan ibadah haji adalah bentuk ibadah terhadap sang pencipta Allah SWT yang dilaksanakan oleh kaum muslim sedunia yang telah siap dan mampu baik secara fnansial, $f$ sik dan keilmuannya. Dengan berkunjung dan melaksanakan beberapa kegiatan dibeberapa tempat di Arab Saudi pada suatu waktu yang dikenal sebagai musim haji (bulan Dzulhijah). Haji adalah berkunjung ke Baitullah, untuk melakukan Thawaf, Sa'i, Wukuf di Arafah dan melakukan amalan-amalan yang lain dalam waktu tertentu (antara 1 Syawal sampai 13 Dzulhijah) untuk mendapatkan keridhaan Allah SWT.

Setiap jamaah haji bebas dalam memilih jenis ibadah haji yang ingin dilaksanakannya. Rasulullah SAW memberi kebebasan dalam hal itu, sebagaimana terlihat dalam hadis berikut.

Aisyah RA berkata: Kami berangkat beribadah bersama Rasulullah SAW dalam tahun hajjatul wada. Di antara kami ada yang berihram, untuk haji dan umrah dan ada pula yang berihram untuk haji. Orang yang berihram untuk umrah ber-tahallul ketika telah berada di Baitullah. Sedang orang yang berihram untuk haji jika ia mengumpulkan haji dan umrah. Maka ia tidak melakukan tahallul sampai dengan selesai dari nahar.

Berikut adalah jenis dan pengertian haji yang dimaksud.

1. Haji ifrad, berarti menyendiri. Pelaksanaan ibadah haji disebut ifrad bila seseorang bermaksud menyendirikan, baik menyendirikan haji maupun menyendirikan umrah. Dalam hal ini, yang didahulukan adalah ibadah haji.

2. Haji tamattu', mempunyai arti bersenang-senang atau bersantaisantai dengan melakukan umrah terlebih dahulu di bulan-bulan haji, lain bertahallul. Kemudian mengenakan pakaian ihram lagi untuk melaksanakan ibadah haji, ditahun yang sama.

3. Haji qiran, mengandung arti meng- 
gabungkan, menyatukan atau mensekaliguskan. Yang dimaksud disini adalah menyatukan atau mensekaliguskan berihram untuk melaksanakan ibadah haji dan umrah.

\section{Manfaat dari sistem perbankan syariah}

Perbankan Islam atau yang lebih dikenal di Indonesia dengan sebutan perbankan Syariah adalah suatu sistem perbankan yang pelaksanaannya berdasarkan hukum Islam (syariah). Prinsip dalam hukum Islam melarang unsurunsur di bawah ini dalam transaksitransaksi perbankan, antara lain:

1. Perniagaan atas barang-barang yang haram,

2. Bunga atau Riba

3. Perjudian dan spekulasi yang disengaja

4. Ketidakjelasan dan manipulatif

Adapun manfaat yang diperoleh dari Perbankan Syariah, antara lain:

1. Dana hanya diinvestasikan pada sektor-sektor yang halal menurut hukum Islam

2. Memakai prinsip muamalah yang diperbolehkan dalam Islam yakni bagi hasil, jual-beli dan sewa-menyewa

3. Berorientasi pada keuntungan dan falah (kebahagian dunia dan akhirat sesuai nilai-nilai Islam)

4. Hubungan dengan nasabah dalam bentuk mitra kerjasama

5. Adanya Dewan Pengawas Syariah yang menjamin nilai-nilai kepatuhan syariah dalam operasional perbankan tidak dilanggar.

\section{Perlunya Optimalisasi penge-} Iolaan dana haji

Anggito Abimanyu, Dirjen Penyelenggaraan Haji dan Umrah (PHU) Kementerian Agama dalam paparannya di seminar nasional "Perhajian: Evaluasi dan Tantangan" di kampus UIN Sunan Kalijaga Yogyakarta pada tahun 2012 yang lalu menegaskan pihaknya akan membuka diri untuk menerima pemikiran cerdas dari penggiat haji dan umrah untuk melakukan perbaikan dan peningkatan dalam melayani jama'ah haji. Setiap tahun tantangan penyelenggaraan haji semakin besar, oleh karena itu tahun depan pemerintah menggelar limar pilar perbaikan yakni reformasi, optimalisasi pengelolaan dana haji, modernisasi sistem informasi haji, peningkatan manasik haji dan revitalisasi asrama haji dan aset-aset haji..

Diantara kelima pilar tersebut, yang paling sering disorot oleh publik dalam penyelengaraan haji adalah mengenai manajemen tata kelola dana haji. Dana haji yang tersimpan dari hasil setoran awal jama'ah kurang lebih mencapai sekitar Rp. 43,5 trilyun. Jika dana sebesar ini dapat dioptimalkan secara ef sien dan produktif tentunya diharapakan akan sangat membantu dalam meningkatkan kesejahteraan pelayanan jamaah haji Indonesia.

Saat ini penempatan setoran dana 
haji jamaah haji lebih banyak terserap pada instrumen-instrumen keuangan syariah seperti sukuk. Padahal jika dana sebesar itu dapat dioptimalkan melalui sebuah lembga keuangan Islam yang secara khusus mengelola dana haji tersebut, tentu akan dapat membantu mengembangkan ekonomi syariah terutama meningkatkan pertumbuhan perbankan syariah di Indonesia.

Tabung Haji Malaysia, sebuah model manajemen haji yang terintegrasi

Tabung Haji Malaysia adalah sebuah lembaga atau perusahaan yang berhubungan dengan kerajaan Malaysia dibawah naungan Menteri Agama Islam Malaysia. Tabung Haji Malaysia beroperasi seperti korporasi dengan organisasi manajemen perusahaan sendiri.

Sistem pengelolaan dana haji di Malaysiaberorientasipadapendekatan bisnis didalam pengembangannya, meskipun lembaga ini dikelola oleh aparat pemerintahan.

Menurut Haji Mohd Khalid bin Mohn Noordin, ketua Tabung Haji Malaysia dalam sebuah wawancara dengan Harian Umum Pelita seusai seminar "Pengelolaan Dana Umat dengan Prinsip Syariah" di Jakarta, mengatakan bahwa investasi Tabung Haji mestilah yang menepati syariah dan pertimbangannya adalah keuntungan yang kompetitif dan berlanjut kepada jama'ah. Dana diinvestasikan di perusahaan atau di tempat-tempat yang tidak ada bau maksiatnya. Semua dana dijalankan dengan sangat hatihati dengan melihat sektor usaha yang Islami.

Setiap tahunnya Tabung Haji sudah membayarkan zakat nasabah kepada Pusat Zakat pemerintah sebesar 2,5 persen. Jadi nasabah haji tidak perlu bingung menghitung berapa zakatnya pada tahun tersebut karena masalah tersebut sudah diurus oleh Tabung Haji. Jadi semua fasilitas dan manfaat dirasakan langsung oleh nasabah secara terus-menerus, karena selain mereka mendapatkan uang dari hasil keuntungan, zakatnya pun sudah dibayarkan, dan bila mau berangkat haji semuanya diurus penuh oleh Tabung Haji Malaysia. Selain itu nasabah tabung haji juga dapat belajar tata cara ibadah haji dari berbagai kursus ibadah haji yang disediakan oleh Tabung Haji di masjid-masjid terpilih diseluruh negara bagian, karena semuanya sudah dipersiapkan oleh Tabung Haji Malaysia. Dalam menetapkan $\mathrm{ONH}$ agar setiap tahunnya tidak terjadi kenaikan yang mendadak, Tabung Haji juga bekerja sama dengan Pemerintah Arab Saudidengan menyewa pondokan dalam jangka waktu yang lama.

\section{METODE PENELITIAN}

\section{Jenis Penelitian dalam Kajian}

Penelitian dalam tulisan ini adalah penelitian kepustakaan, yakni penelitian yang data-data dan 
informasinya diperoleh dari sumber pustaka (bacaan) baik berupa bukubuku, hasil penelitian dan bahan bacaan yang lainnya (Supardi, 2005:35).

\section{Teknik Pengumpulan Data}

Dalampenelitianyangdilaksanakan ini, penulis menggunakan teknik pengumpulan data literatur yaitu dengan mengumpulkan literatur-literatur yang berhubungan dengan penelitian ini, kemudian dianalisis dan diambil kesimpulan.

\section{Sumber Data}

Penelitian ini menggunakan teknik pengumpulan data literatur, maka bahan yang digunakan dalam penelitian ini hanyalah data sekunder. Data sekunder tersebut berupa bahan yang diperoleh dari jurnal internasional IDB, buku, majalah, dan artikel online dari media internet yang memiliki relevansi dengan permasalahan dalam obyek penelitian.

\section{Metode Analisis Data}

Analisis data yang digunakan adalah deskriptif-kualitatif. Dengan metode ini, masalah dan fakta akan digambarkan secara deskriptif, kemudian dianalisis guna memperoleh gambaran utuh tentang objek yang dikaji. Kegiatan analisis kualitatif, seperti yang dipaparkan Maatthew B. Milles dan A. Micheal Huberman, melibatkan kegiatan reduksi data, pengujian data dan penarikan kesimpulan (Miles dan Huberman, Tanpa Tahun).

\section{HASIL DAN PEMBAHASAN}

\section{Manajemen Pengelolaan Dana}

\section{Haji Saat Ini}

Jumlah jama'ah haji dari Indonesia adalah yang paling banyak dibandingkan dengan negara-negara lain di dunia yakni setiap tahunnya selalu memperoleh kuota hingga 200 ribu lebih jama'ah. Seiring dengan meningkatnya pertumbuhan ekonomi, jumlah jama'ah haji Indonesia semakin mengalami peningkatan dari tahun ke tahun. Hal ini terbukti dengan jumlah jama'ah haji tahun 2004 lalu adalah jumlah terbanyak dari tahun-tahun sebelumnya yaitu sejumlah 204.945 orang (www.haji.kemenag.go.id, 2012). Penyelenggaraan kegiatan ibadah haji ditanah air dilaksanakan oleh Direktorat Jenderal (Dirjen) Penyelenggaraan Haji dan Umrah dibawah naungan Kementerian Agama Republik Indonesia. Hal ini sesuai dengan UU No. 17 Tahun 1999 tentang Penyelenggaraan Ibadah Haji yang menetapkan bahwa penyelenggaraan haji merupakan tugas nasional dan menjadi tanggung jawab pemerintah dibawah koordinasi Menteri Agama.

Saat ini aliran kas setoran awal dana haji (BPIH) yang dibayarkan oleh jama'ahuntukmemperolehnomorantrian haji hanya diinvestasikan ke instrumeninstrumen keuangan tabungan deposito 
di Bank Indonesia maupun dibeberapa Bank Penerima Setoran (BPS) dan diinvestasikan pula ke Surat Beharga Syariah Negara (SBSN) atau sukuk yang setiap tahunnya memperoleh laba sebesar 1,5 triliun atau sebesar $7,5 \%$.

\section{Solusi Terdahulu}

Saat ini pengelolaan hingga pemanfaatan optimalisasi dana haji Indonesiasudah diatur dalamUUNo.13 tahun 2008 tentang Penyelenggaraan Ibadah Haji sebagai landasan hukum. Banyak pihak menganggap landasan hukum tersebut belum cukup, sehingga diperlukan UU tersendiri yang mengatur tentang tata kelola dana haji. Namun dalam UU No.13 tahun 2008 tersebut pengelolaan hanya terbatas pada pemanfaatan optimalisasinya dan pengembangannya dalam bentuk instrument bank yang benar-benar terjamin keamanannya. Seperti dalam tabungan deposito serta dalam SBSN (Surat Berharga Syariah Negara) atau sukukdengannilaioptimalisasisebesar $7,5 \%$ pertahun. UU tersebut hanya terfokus pada penyelenggaraan ibadah haji, karena setoran awal merupakan bagian dari penyelenggaraan haji, maka disinggung sedikit didalamnya. UU tersebut juga dijelaskan bahwa pengelolaan dana haji di Indonesia hanya bersifat nirlaba, tidak ada aturan bahwa dana setoran awal haji boleh diproduktifkan untuk memperoleh prof $t / l a b a$.

Potensi dana haji yang bisa dikelola jumlahnya bisa mencapai lebih dari Rp 25 triliun. Namun saat ini dana haji yang baru dikelola oleh bank Syariah porsinya hanya $28,73 \%$ atau sekitar Rp 7,44 triliun sisanya yang $71,27 \%$ atau sebesar $R p 18,44$ dikelola oleh bank konvensional. Sebuah hal yang dilematis karena dana haji yang notabanenya terkait dengan pelayanan umat Islam tetapi masih ada dalam pengembangan dananya ke instrument keuangan dengan sistem bunga (riba), padahal dalam Islam sudah sangat jelas dikatakan bahwa bunga/riba itu adalah haram, seharusnya pengelolaan dan pengembangan dana haji dikelola sepenuhnya dengan sistem ekonomi Islam.

Berdasarkan data dari Kemenag, hanya tiga bank Syariah dari sekitar 22 bank yang ditunjuk untuk mengelola dana haji, diantaranya yaitu Bank Muamalat Indonesia (BMI), Bank Syariah Mandiri (BSM), dan Bank Mega Syariah (BMS).

\section{Bank Haji Indonesia untuk} Meningkatkan

\section{Jama'ah Haji}

Gagasan ide untuk mendirikan Bank Haji Indonesia (BHI) yang saya paparkan dalam jurnal ini nantinya ada dua alternatife pilihan yang saya usulkan, pertama Bank Haji Indonesia (BHI) bisa berupa Badan Usaha Milik Negara (BUMN) dibawah naungan Kementerian BUMN yang dikelola 
secara profesionalitas oleh ahli-ahli keuangan dan perbankan Syariah serta ahli ekonomi dan hukum Islam. Jika $B H I$ berupa BUMN, hal ini berarti fungsinya hampir sama dengan bankbank Syariah pada umumnya yakni ada proses penghimpunan dana, penyaluran pembiayaan, Investasi di sektor keuangan. Dengan demikian berarti $\mathrm{BHI}$ berorientasi prof $\mathrm{t}$ oriented dengan tetap menfokuskan pelayanan maksimal pengelolaan dana haji untuk kesejahteraan nasabah (jama'ah haji). Lalu jika BHI berupa Badan Layanan Umum (BLU) dibawah naungan Kementerian Agama bentuknya tidak akan jauh berbeda dengan Lembaga Tabung Haji milik Malaysia.

\section{Mencontoh Model Manajemen} Pengelolaan Dana Haji Tabung Haji Malaysia

Dalam kata pengantar dari Dr Omar Zuh, Deputy Director IDB dalam jurnal berjudul Tabung Haji as an Islamic Financial Institution : The Mobilization of Investment Resources in an Islamic Way and The Management of Hajj yang diterbitkan oleh IRTI-IDB (Islamic Research and Trainning InstituteIslamic Development Bank) yang kami baca, dinyatakan bahwa Tabung Haji
Malaysia (The pilgrims Management and Fund Board of Malaysia) sebagai lembaga yang mampu memobilisasi tabungan haji induvidu dari penabung kecil dan berhasil meraih laba dari investasi pada sektor pertanian, industri, perdagangan dan real estate yang dioperasikan dengan cara-cara yang sesuai prinsip syariah untuk kesejahteraan dan pelayanan jamaah haji Malaysia melalui bagi hasil yang diberikan Tabung Haji Malaysia ke nasabahnya.

Tujuan didirikannya Tabung Haji oleh Pemerintah Malaysia diantara untuk 1). Memberikan pelayan terbaik kepada jama'ah haji Malaysia melalui berbagai fasilitas dan jasa yang disediakan Tabung Haji 2). Mendorong umat muslim mempersiapkan tabungan haji mereka dari semenjak dini 3). Mendorong umat muslim untuk ikut berinvestasi di sektor pertanian, perdagangan, industri dan real estate yang berdasarkan prinsip syariah (IDB Journal, 1995).

Dalam segi pelayanan haji, Tabung Haji Malaysia memiliki struktur yang tersusun sistematis yang satu dengan yang lainnya saling membentuk satu kesatuan. Hal ini bisa kita lihat dalam diagram graf $k$ dibawah ini: 
Bank Haji Indonesia : Optimalisasi Pengelolaan Dana....., Riko Nazri

MAIN HAJ SERVICES

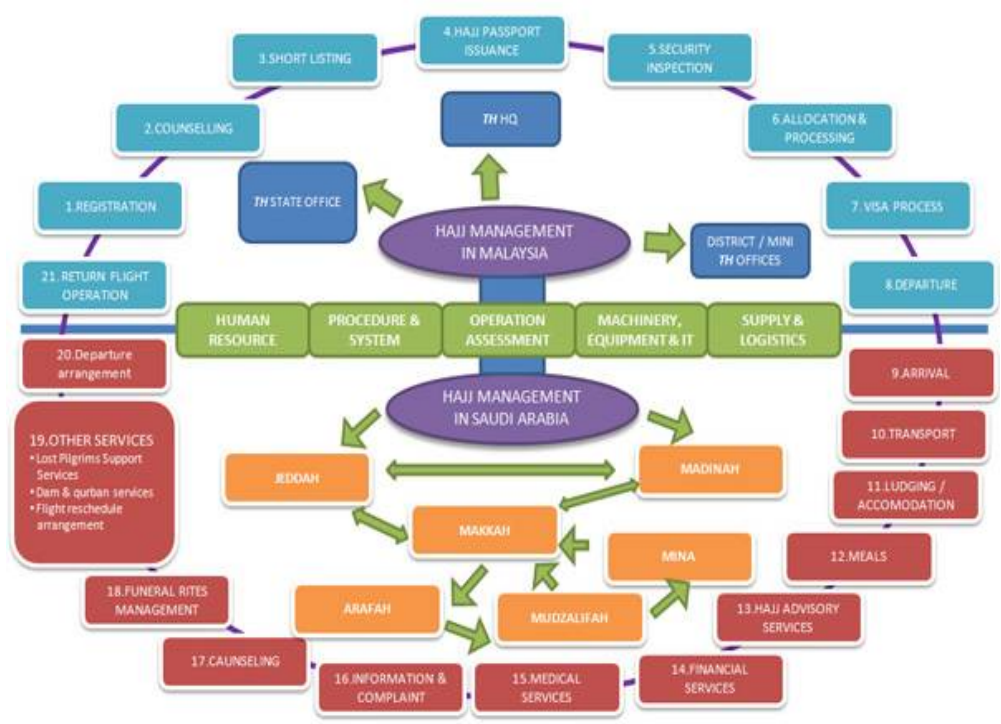

Gambar 1. Diagram Manajemen Pelayanan Haji di Malaysia (www.tabunghaji. gov.my diakses 2012)

Berikut ini adalah beberapa oleh Kementerian Agama dengan perbedaan pelayanan haji antara Pemerintah Malaysia yang dikelola Pemerintah Indonesia yang dikelola oleh Lembaga Tabung Haji.

Tabel 1. Perbandingan Pelayanan Haji Indonesia dengan Malaysia

\begin{tabular}{|l|l|l|}
\hline \multicolumn{1}{|c|}{ URAIAN } & \multicolumn{1}{c|}{ INDONESIA } & \multicolumn{1}{c|}{ MALAYSIA } \\
\hline Kuota pertahun & 210.000 orang & 26.000 orang \\
\hline Biaya Keseluruhan per jamaah & $\mathrm{Rp} 32.000 .000$ & $\mathrm{Rp} 49.000 .000$ \\
\hline Dibayarkan langsung & $\mathrm{Rp} 27.000 .000$ & $\mathrm{Rp} 29.940 .000$ \\
\hline Dibayarkan penyelenggara & $\mathrm{Rp} 5.000 .000$ & $\mathrm{Rp} 9.000 .000$ \\
\hline Penabung/ calon jemaah haji & $\mathrm{Rp} 1.400 .000$ orang & $\mathrm{Rp} 700.000$ \\
\hline Rata-rata wait nglist & 6 tahun & 26 tahun \\
\hline Sewa pemondokan di mekkah & SAR 3400 & SAR 6000 \\
\hline Prinsip pengelolaan keuangan & Nirlaba & Komersial \\
\hline $\begin{array}{l}\text { Negara yang belajar } \\
\text { Manajemen Haji dari Indonesia }\end{array}$ & Rusia, Iran, Nigeria, Cina, Turki, & \\
\hline Standar mutu pelayanan & Aljazair. & - \\
\hline Penetapantanif & ISO 9001:2008 & ISO 9001:2008 \\
\hline
\end{tabular}

(Sumber : Majalah Realita Haji, November 2009) 
Jika kita cermati hasil perbandingan dari data-data diatas memang dalam banyak hal komponen-komponen penyelenggaraan haji di Indonesia lebih unggul, mulai dari jumlah kuota yang disediakan, jumlah daftar tunggu yang relative lebih cepat ratarata hanya sampai 6 tahun hingga BPIH (direct cost) yang lebih murah, sampai ada beberapa negara yang ingin mempelajari Manajemen Haji di Indonesia. Namun dari sudut pandang (perspektif) saya, saya menganalisis Manajemen Pengelolaan Dana Haji di Malaysia lebih bagus dan optimal, hal ini menurut saya karena beberapa hal, antara lain:

1. Pengelolaan dana haji yang berprinsip proft, sehingga dari hasil proft yang diperoleh Tabung Haji Malaysia (THM) tersebut dimanfaatkan untuk meningkatkan pelayanan jama'ah hajinya seperti memberikan bagi hasil dari prof $t$ yang diperoleh kepada nasabah haji sampai dengan membantu pembangunan nasional.

2. Dikelola oleh badan/lembaga diluar pemerintahan sehingga ada aturan

3. jelas antara pemerintah sebagai regulator dan THM sebagai operator.

4. Anak-anak disana sejak usia dini sudah didaftarkan oleh orang tuanya

5. untuk mengikuti tabungan haji

6. Laporan keuangannya yang lebih transparan dan akuntabilitas.

\section{Bank Haji Indonesia (BHI) Bisa Menjadi Solusi Alternatif}

Dengan total dana haji yang tidak kecil, jika pendirian Bank Haji Indonesia $(\mathrm{BHI})$ dapat direalisasikan, maka $\mathrm{BHI}$ akan menjadi bank syariah dengan asset terbesar suatu hari nanti. Saat ini bank syariah dengan asset terbesar dipegang oleh Bank Syariah Mandiri (BSM) dengan asset sebesar Rp 24 triliun disusul oleh Bank Muamalat Indonesia (BMI) dengan jumlah asset sekitar Rp 15 triliun.

Tantangan dalam mengimplementasikan pendirian $\mathrm{BHI}$ ini salah satunya ialah diperlukan modal yang besar sebagai modal awal operasionalnya, setidaknya diperlukan modal awal sebesar Rp 3 triliun untuk back up resiko atas dana kelolaan sekitar Rp 30 triliun, namun hal tersebut bisa diatasi dengan menjadikan Dana Abadi Umat (DAU) sebagai alternatif unsur modal awalnya.

Melirik konsep pengelolaan dana haji di Malaysia melalui Tabung Haji Malaysia (THM), dimana pengelolaan dana haji disana memiliki peran dalam pembangunan nasional. Salah satu bentuk keberhasilan THM yakni, saham tabung haji Malaysiaselaluberkontribusi dalam setiap pembangunan nasional, seperti dalam pembangunan menara petronas, lapangan balap sirkuit sepang, bandara dan jalan tol. THM juga mampu memberikan bagi hasil kepada nasabah haji sehingga dari bagi hasil yang didapatkan tersebut 
dapat membantu pelunasan sisa biaya perjalanan haji mereka. Jika Malaysia saja bisa seperti itu, kenapa kita sebagai negara dengan pengirim jama'ah haji terbesar belum mampu berbuat lebih dari Malaysia dalam hal tata kelola keuangan haji yang lebih optimal

Bila dana haji yang berjumlah triliunan tersebut dikelola oleh Bank Haji Indonesia misalnya, maka bagi hasilnya (prof tsharing) akan dibagikan kepada jama'ah haji Indonesia, bahkan bisa-bisa nantinya Bank Haji Indonesia memiliki hotel dan pemondokan permanen bagi jama'ah haji kita di Makkah dan Madinah. Ketika bukan musim haji juga dapat dikomersilkan dengan menyewakan kepada jama'ah umrah dari Indonesia maupu luar Indonesia. Karena ekonomi haji ini tidak akan pernah habis sepanjang dunia ini belum kiamat.

\section{Pihak-pihak yang Terkait dalam} Implementasi Bank Haji Indonesia

\section{Kementerian Agama Republik} Indonesia, Kemenag RI sebagai regulator dan penanggung jawab atas penyelenggaraan haji, menjamin memberikan pelayanan maksimal kepada jama'ah haji mulai dari Indonesia sampai di Arab Saudi

2. Kementerian Keuangan Republik Indonesia, membuat regulasi mengenai tata kelola dana haji tersebut sekaligus sebagai pembina teknis dalam operasionalnya.

3. Dewan Perwakilan Rakyat Republik Indonesia (DPR-RI), dalam hal ini DPR RI berfungsi sebagai pembuat keputusan untuk mensahkan merevisi UU No. 13 Tahun 2008 tentang penyelengaraan haji dan umrah dan membahas mengenai

4. Dewan Pangawas Syariah-Majelis Ulama Indonesia (DSN-MUI), sebagai lembaga yang bertugas mengawasi kepatuhan Syariah pada operasional Bank Haji Indonesia

5. Jamaah (Nasabah) Bank Haji Indonesia, berperan sebagai objek dari Bank Haji Indonesia, dimana dari nasabah haji inilah nantinya dana-dana setoran awal tersebut dihimpun.

\section{Langkah-langkah Strategis Implementasi Bank Haji Indonesia (BHI)}

Untuk mengimplementasikan pendirian Bank Haji Indonesia yang secara konsep dasarnya tidak berbeda jauh dengan Tabung Haji Malaysia dan hanya akan ada sedikit perubahan-perubahan yang tentunya disesuaikan dengan regulasi yang berlaku dinegara ini perlu adanya strategi-strategi khusus. Langkahlangkah strategis yang perlu dilakukan untuk mengimplementasikan Bank Haji Indonesia dapat terlihat dalam graf k berikut; 


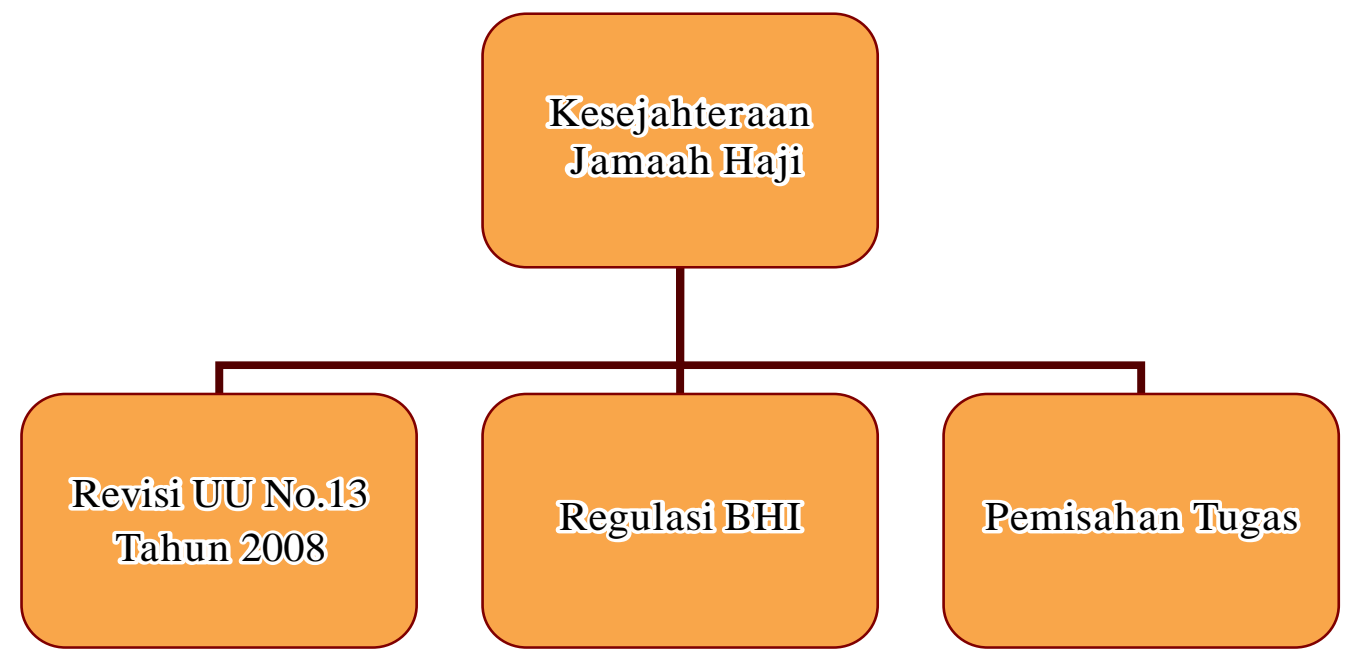

Gambar 3. Diagram Langkah Strategis Implementasi BHI

Keterangan:

1. Langkah awal yang harus dilaksanakan ialah merevisi UU No.13 Taun 2008 Tentang Penyelenggaraan Ibadah Haji yang berprinsip nirlaba untuk dibolehkannya berprinsip prof $t$ oriented dengan catatan prof $t$ tersebut untuk kesejahteraan bersama

2. Untuk mendirikan sebuah lembaga pastidiperlukansebuahregulasiyang mengaturnya, dalam implementasi $\mathrm{BH}$ ini dibutuhkan peran besar dari Kemenag, Kemenkeu dan Bank Indonesia dalam membuat regulasi tersebut.

3. Harus adanya pemisahan tugas yang jelas didalam penyelenggaraan haji ini, antara yang bertanggung jawab sebagai regulator dan yang berperan sebagai operatornya.

\section{KESIMPULAN}

Dari pembahasan diatas dapat disimpulkan, apabila lembaga Bank Haji Indonesia (BHI) tersebut dapat di implementasikan dinegeri kita Indonesia, maka kedepannya manajemen pengelolaan keuangan haji di Indonesia akan lebih baik. Bank Haji Indonesia sebagai Penanggung Jawab seluruh tata kelola keuangan haji akan mengoptimalkan seluruh setoran awal (BPIH) tersebut untuk kesejahteraan pelayanan jama'ah haji. $\mathrm{BHI}$ juga akan menjadi bank Syariah dengan asset, hal ini tentunya akan mendorong pertumbuhan perbankan Syariah nasional dan berkontribusi dalam membantu pembangunan nasional. Sehingga transparansi dan akuntabilitas dalam pengelolaannya pun menjadi jelas karena dikelola 
dengan profesionalitas oleh ahli-ahli yang kompeten dalam hal tersebut.

\section{Teknik Implementasi}

Dalam proses implementasi dibutuhkan hal teknis, teknik yang diberikan pada gagasan ini terfokus pada empat pokok antara lain;

1. Mengatur peningkatan asas manfaat atas pengelolaan keuangan haji yang

2. bersumber dari dana setoran awal jemaah calon haji

3. Pemberian batasan atau ramburambu pengelola keuangan haji, agar benar-benar aman

4. Perlunya dibentuk suatu lembaga pengelola keuangan haji

5. Mengatur masalah penanggung jawab atas pengelolaan keuangan haji sekaligus pembinanya. Yakni penanggung jawabnya Menteri Agama dan Pembina teknisnya Menteri Keuangan dan Pembina syariahnyaadalahDewanPengawas Syariah.

\section{Prediksi Hasil}

Untuk segera menerapkan konsep Bank Haji Indonesia (BHI) memang membutuhkan waktu yang tidak sebentar, karena langkah awal yang harus dilakukan ialah membuat UU dan regulasi yang mendukung diterapkannya pendirian BHI ini. Perlu ada peran besar dari Kementerian Agama, Dewan Perwakilan Rakyat dan Bank Indonesia. Jika pihak- pihak yang memiliki wewenang mengimplementasikan $\mathrm{BHI}$ ini dapat saling bekerja sama dengan baik satu sama lain dan memiliki komitmen yang besar untuk melayani ummat. Maka sangat mungkin $\mathrm{BHI}$ ini akan segera terwujud memberikan manfaat banyak untuk jamaah haji Indonesia.

Semua konsep yang dirancang tentunya diawali dengan suatu hipotesa mengenai hasil. Rencana mengenai hasil yang akan dicapai ialah akan terpusatnya tata kelola keuangan haji sehingga tata kelola keuangan haji akan transparan dan akuntabilitas, adanya bagi hasil yang diperoleh oleh nasabah haji dari prof $t$ $\mathrm{BHI}$ dan yang paling utama ialah dari hasil optimalisasi dana haji tersebut digunakan untuk meningkatkan kesejahteraan jama'ah haji Indonesia dan membantu pembangunan nasional.

\section{DAFTAR PUSTAKA}

IDB Prize Winners' Lecture Series No. 4. 1995. Tabung Haji as an Islamic

Financial Institution : The Mobilization of Investment Resources in an Islamic Way an The Management of Hajj. Jeddah : IRTI Islamic Development Bank.

Majalah Realita Haji Edisi IV Tahun 2011

Majalah Sharing Edisi 35 Thn IV November 2009 hal 46

Miles, Matthew B. Dan A. Micheal Huberman. Tanpa tahun. Analisis 
Data Kualitatif. (terj. Tjetjep Rohendi Rohidi). Jakarta: UI Press.

Supardi. 2005. Metodologi Penelitian Ekonomi dan Bisnis. Yogyakarta: UII Press.

h t t p://bwi.or.id/index. $\mathrm{ph} \mathrm{p}$ ? o ption = c o m _ content $\&$ view $=$ article $\& i d=636$ : tiga-alternatif-pengelolaan-danahaji\&catid=14:lintasberita\& Item id=134\&lang=ar diakses pada tanggal 14 febuari 2012

http://harian-pelita.pelitaonline. com/cetak/2013/01/30/meliriktabung-haji-malaysia-untukmembangun-kesejahteraanumat\#.UTg1DDewOSo diakses 07 maret 2013 http://ib.eramuslim.com/2010/05/31/ dirikan-bank-syariah-hajisolusikah/ diakses 14 febuari 2012.

http://www. infobanknews. com/2011/01/kemana-alirandana-haji-mengalir/ diakses 20 Febuari 2012.

http: / / www.halaljournal. c o m/article / 5392 / howmalaysia\%C3\%A2ae\%E2\% $84 \%$ A2s-tabung-haji-couldprovide-haj-f nancing-a-shariahcompliant-model diakses 20 feb 2012.

www.haji.kemenag.go.id diakses 14 febuari 2012

www.tabunghaji.go.my diakses 14 febuari 2012 